\title{
PRZESTĘPCZOŚĆ BIAŁYCH KOŁNIERZYKÓW W ŚWIETLE AMERYKAŃSKICH TEORII KRYMINOLOGICZNYCH. ANALOGIE DO POLSKICH REALIÓW
}

Zjawisko przestępczości tzw. „białych kołnierzyków” jest nieodłącznym elementem rzeczywistości dzisiejszego świata. Rozpowszechnianiu występowania tego zjawiska sprzyja brak kontroli w przedsiębiorstwach, wysoka specjalizacja sprawców, ich status społeczny oraz trudności w ściganiu.

Definicja przestępcy w białym kołnierzyku została zaproponowana przez Edwina Sutherlanda w latach 40-tych XX wieku. Odwoływała się ona do kryterium sprawcy. Według Sutherlanda termin ten obejmował przestępstwa popełniane przez osoby cieszące się uznaniem i wysoką pozycją społeczną oraz w ramach ich działalności zawodowej (In the course of his occupation). ${ }^{1}$

Celem definicji E. Sutherlanda jest rozróżnienie przestępcy w białym kołnierzyku spośród sprawców z niższych klas społecznych, popełniających pospolite przestępstwa niezwiązane $\mathrm{z}$ wykonywanym przez nich zawodem.

Zdefiniowanie w ten sposób pozycji tzw. „białego kołnierzyka” pozwala postrzegać go jako jednostkę niebezpieczną, wykorzystującą swój status społeczny do popełniania różnych przestępstw gospodarczych. Działania tzw. „białego kołnierzyka" można opisać w trzech tezach:

1. Zamiar popełnienia przestępstwa jest ściśle związany z procedurami, których sprawca się podejmuje podczas wykonywania swojego zawodu,

2. Skutki jego działania są niezauważalne przez otoczenie,

3. Sprawca kamufluje się, wskazując, że wiele innych osób codziennie wykonuje takie same procedury w pracy.

Według E. Sutherlanda jego własny model przestępcy odpowiada cechom zawodowych złodziei. Sprawcy obu klas są w większości recydywistami. Obydwie

1 J. Błachut, A. Gaberle, K. Krajewski, Kryminologia, Gdańsk 2007, s. 294. 
grupy przestępcze charakteryzują się wysokim stopniem zorganizowania. Zawodowi złodzieje uważani są przez społeczeństwo za przestępców. Natomiast „,białe kołnierzyki" oceniani są jako osoby, które w wyniku pomyłki bądź zaniedbania zostały złapane na gorącym uczynku i mimo wykrycia oraz postawienia zarzutów nie tracą wysokiego statusu społecznego. Stwierdza on, że na to, w jaki sposób kogoś oceniamy, ma wpływ jego status, pełniona funkcja oraz zaufanie społeczne do instytucji, w której dana osoba pracuje. ${ }^{2}$

Sutherland przeprowadził szerokie badania nad nadużyciami w amerykańskich firmach. Okazało się, że $97 \%$ spośród 70 badanych spółek handlowych popełniało przestępstwa gospodarcze. Badania te zostały przeprowadzone w latach 50-tych ubiegłego stulecia i były podstawą do sformułowania pojęcia tzw. ,,białych kołnierzyków". ${ }^{3}$ Podstawą do wyodrębnienia tej kategorii przestępczości była niewątpliwie teoria zróżnicowanych powiązań, która została po raz pierwszy zaprezentowana w pracy pt. „Principles of Criminology” z 1939 r. ${ }^{4}$ Jej zmodyfikowana wersja opublikowana została w 1947 r. i zawierała dziewięć następujących założeń:

1. Zachowanie przestępne jest wyuczone.

2. Zachowanie przestępne zostaje $\mathrm{w}$ interakcjach $\mathrm{z}$ innymi osobami $\mathrm{w}$ procesie komunikowania się.

3. Zasadnicza część uczelnia się przestępnego zachowania dokonuje się w grupach o bliskich osobistych powiązaniach.

4. Gdy zachowanie przestępne jest wyuczone, to uczenie obejmuje a)techniki popełniania przestępstw, które są niekiedy bardzo skomplikowane, a niekiedy bardzo proste, b) specyficzne ukierunkowanie motywów, dążeń, racjonalizacji i postaw.

5. Specyficzne ukierunkowanie motywów i dążeń jest wyuczone w powiązaniu z określeniem norm prawnych jako wiążących bądź niewiążących.

6. Jednostka staje się przestępcą wskutek nadwyżki definicji sprzyjających naruszaniu przepisów prawa i definicjami nie sprzyjającymi naruszeniu przepisów prawa.

7. Zróżnicowane powiązania mogą się różnić częstotliwością, trwałością, pierwotnością i intensywnością.

G. Potter, L. Gaines, Underwords and Upperworlds: The Convergence of Organized and White Collar Crime, (w:) Proceedings of the academic workshop: Definitional Dilemma: Can and Should There be a Universal Definition of White Collar Crime?, June 20-22, West Virginia University, 1996, s. 31-32

3 E. Sutherland, White collar crime, Yale University Press 1983, s. 228.

4 Teoria z 1939 r. odnosiła się do przestępczości w ogóle. Została zrewidowana, aby trafniej ocenić zjawisko wobec osób krytykujących pogląd Sutherlanda. 
8. W procesie uczenia się zachowań przestępnych poprzez powiązania z kryminalnymi i antykryminalnymi wzorcami występują te wszystkie mechanizmy, które występują przy każdym uczeniu się.

9. Zachowanie przestępne jest wyrazem ogólnych potrzeb i wartości, nie można go wyjaśnić, odwołując się do tych potrzeb i wartości, gdyż zachowanie nieprzestępne jest wyrazem tych samych potrzeb i wartości. ${ }^{5}$

Niektórzy kryminolodzy amerykańscy starali się zaadaptować tę teorię, przeprowadzając dodatkowe badania. Przykładowo obliczali dla określonej osoby liczbę potencjalnych przyjaciól-przestępców, po czym dopasowywali swoje wyniki do modelu uczenia się zachowań przestępczych. ${ }^{6}$

Przyjmuje się, że koncepcja ta nie może być jednoznacznie traktowana jako teoria wyjaśniająca rozkład nasilenia przestępczości w poszczególnych warstwach czy segmentach społeczeństwa. Trudno zakwalifikować ją jako typową teorię socjologiczną, ponieważ uczenie się jako proces ma charakter psychospołeczny. Niejasności wynikają też z ogólnikowości twierdzeń w niej przyjętych. Nie ma jednak wątpliwości, że teoria ta powstała na gruncie paradygmatu pozytywistycznego i w pełni oddaje założenia kierunku socjologicznego.

\section{Przestępczość białych kołnierzyków w Stanach Zjednoczonych}

Od czasu wykreowania teorii przez Edwina Sutherlanda w USA powstało szereg innych niezwykle interesujących koncepcji socjologiczno-kryminologicznych. Warto wymienić tu kilku autorów, których teorie dotyczące przestępczości białych kołnierzyków są odnotowywane zarówno w literaturze socjologicznej, jak i w kryminologii. Są to: Gilbert Geis (teorie dotyczące zachowań dewiacyjnych w komórkach rządowych), Michael Gottfredson i Travis Hirschi (teoria samokontroli), Neal Shover i Andy Hochstetler (teoria racjonalnego wyboru) oraz James W. Coleman (teoria okazji i motywacji).

Ten ostatni zebrał szczególnie pochlebne recenzje w związku z podjętymi badaniami nad przestępczością białych kołnierzyków. ${ }^{7}$ Skupił się na dwóch uwarunkowaniach - motywacji i okazji. Motywacją dla działań przestępcy w białym kołnierzyku jest dążenie do uzyskiwania coraz większych dochodów bez względu na aktualny status materialny. ${ }^{8}$ Zdaniem Jamesa W. Colemana „osoby, które nie potrze-

\footnotetext{
E. Sutherland, Principles of Criminology. (wyd. 4), Philadelphia 1947, s. 47-58.

G. Geis, White-collar and Corporate Crime, New Jersey, 2007, s. 161-162.

James W. Coleman, Toward an Integrated Theory of White-Collar Crime, American Journal of Sociology 1987, nr 93, s. 408.

R.F. Meier, G. Geis, The White-Collar Offender, (w:) H. Toch, Psychology of Crime and Criminal Justice, New York, 1979, s. 441.
} 
bują dodatkowych pieniędzy, zrobią wszystko, aby je zdobyć". ${ }^{9}$ Uważa on, że przed erą przemysłową nie było wystarczającej nadwyżki bogactwa, aby powstawały tego typu zachowania w konkurencji pomiędzy przedsiębiorcami.

Drugim istotnym terminem definiowanym przez Colemana jest okazja. Przedstawia ją na czterech płaszczyznach. Pierwsza płaszczyzna opiera się na stwierdzeniu ,co określona osoba może osiągnąć wykorzystując okazję np. pieniądze, status, satysfakcje". Druga to sankcja związana z czynem przestępnym, który dana osoba chce popełnić. Trzecia polega na porównywaniu okazji z racjonalnymi pomysłami na wykonanie zaplanowanego przestępstwa. Natomiast ostatnią płaszczyzną jest porównanie tej okazji do innych, których dana osoba jest świadoma. ${ }^{10}$

\section{Rys. 1 - Typy przestępczości białych kołnierzyków w USA}

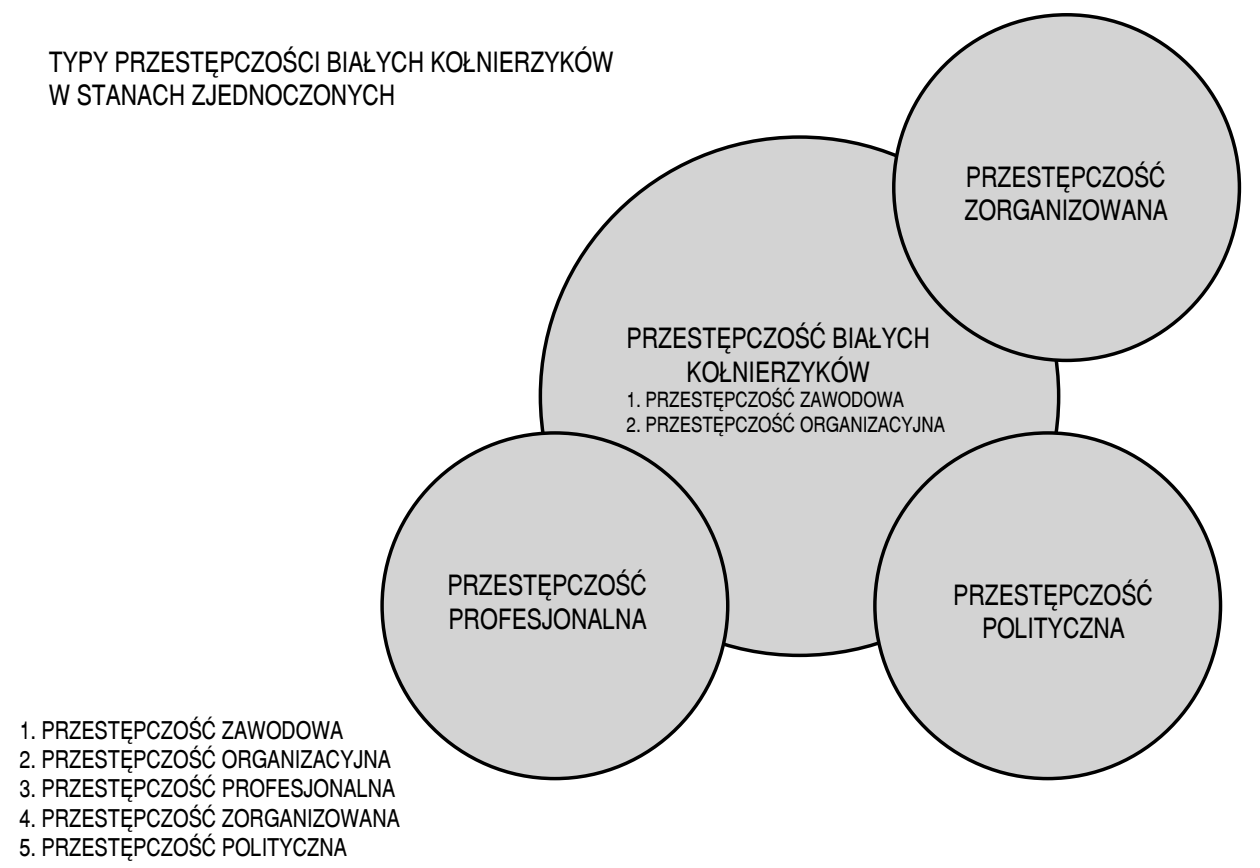

Amerykańscy kryminolodzy uznali w swoim systemie prawnym przestępczość zawodową i organizacyjną jako podstawowe formy działalności przestępców w tzw. „białym kołnierzyku” i utworzyli następujący schemat przedstawiający rozkład tej przestępczości w USA:

$9 \quad$ P.C. Whybrow, American Mania: When More Is Not Enough, New York 2005.

10 J.W. Coleman, op. cit., s. 424. 
Według klasyfikacji zaproponowanej przez H. Edelhertza (1970 r.) występują następujące kategorie przestępstw dotyczące przestępczości zawodowej, organizacyjnej i profesjonalnej:

1. Przestępstwa skarbowe.

2. Przestępstwa wewnętrzne, popełniane przez osoby pełniące kierownicze funkcje, polityków lub urzędników w związku z działalnością finansową podmiotów, w których są oni zatrudnieni.

3. Przestępstwa związane $\mathrm{z}$ operacjami bankowymi, popełniane w związku z działalnością gospodarczą określonego przedsiębiorcy.

4. Przestępczość jako główna forma aktywności biznesowej sprawcy. ${ }^{11}$

\section{Przestępczość polityczna}

Aby spojrzeć z innej perspektywy na przestępczość białych kołnierzyków, należy zwrócić uwagę na współczesną przestępczość polityczną, której najważniejszą formą walki jest osiąganie władzy i dążenie do wdrażania ideologicznych celów.

W epoce coraz większego rozwoju technologicznego - udoskonalania środków i sposobów masowego zabijania, sprawcy zaczęli jeszcze silniej niż dotychczas ingerować w politykę wewnętrzną i zewnętrzną państw. Przestępstwa polityczne obejmują czyny popełniane z pobudek ideologicznych i ukierunkowane są przeciwko działalności państwa.

Wielkie skandale międzynarodowe, takie jak: sprawa Bank Kredytu i Handlu Międzynarodowego, sprawa Iran-contra oraz sprawa Iraqgate pokazują, jak poważna jest skala przestępczości białych kołnierzyków w tym obszarze.

Bank Kredytu i Handlu Międzynarodowego był trzecią co do wielkości instytucją bankową, której działalność była przyczyną jednego z największych upadków bankowości w historii.

Udział w tej aferze miały m.in.: agencje i oddziały rządowe, grupy terrorystyczne, handlarze narkotyków oraz organizacje przestępcze. Nielegalna działalność banku była rozwinięta na międzynarodową skalę. Działalność tego banku polegała m.in. na: fałszowaniu kont bankowych, oszustwach gospodarczych, praniu pieniędzy, finansowaniu nielegalnego handlu bronią oraz programów nuklearnych, działaniach korupcyjnych w sferze polityki oraz na nielegalnych działaniach w obrębie agencji rządowych. Sprawa Iran-contra dotyczyła potajemnej sprzedaży broni do Iranu. Uzyskane w ten sposób środki finansowe najprawdopodobniej przeznaczone zostały na operację przeciwko Nikaragui.

11 F. Hagan, M. College, Varieties of White Collar Crime: Corporate, Organizational, Occupational, Organized, Political and Professional, (w:) Proceedings of the academic workshop: Definitional Dilemma: Can and Should There be a Universal Definition of White Collar Crime?, June 20-22, West Virginia University, 1996, s. 232-233. 
Upadek instytucji kredytowych, a w tym kas oszczędnościowo-kredytowych, był spowodowany brakiem inicjatywy w dochodzeniu spraw dotyczących ,,prania pieniędzy". Oceniono, że upadłość 22 firm kredytowych w USA uzależniona była od takiej działalności. ${ }^{12}$

\section{Przestępczość białych kołnierzyków w Polsce}

Przestępczość białych kołnierzyków nie została usystematyzowana w polskim systemie prawnym. Na tle definicji przyjętych w Stanach Zjednoczonych rodzimą przestępczość białych kołnierzyków można postrzegać w następujących obszarach:

Rys. 2 - Typy przestępczości białych kołnierzyków w Polsce

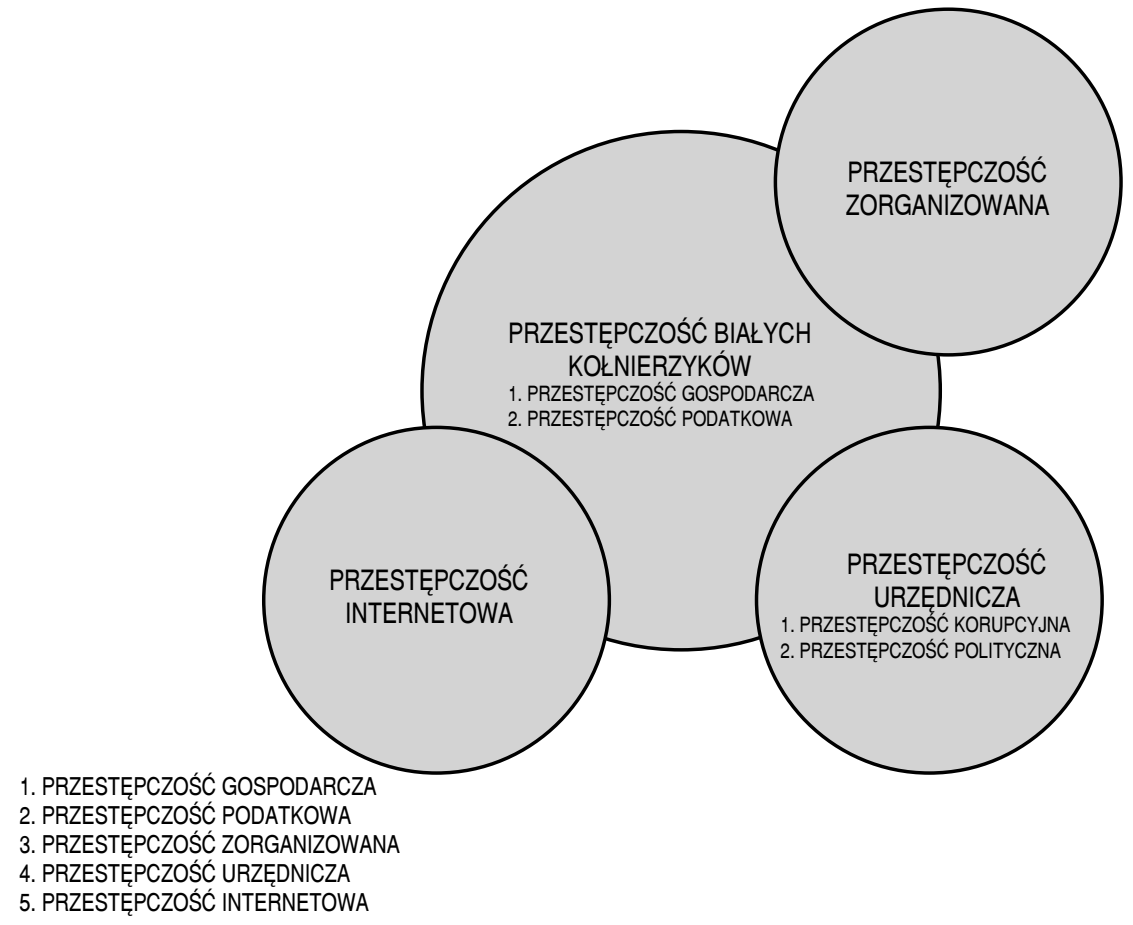

Zakres przestępczości gospodarczej w Polsce jest szeroki, dlatego poniższa typologia będzie zawierała wyłącznie grupę przestępstw gospodarczych związanych $\mathrm{z}$ definicją przestępczości białych kołnierzyków. Są to:

- przestępstwa przeciwko podstawowym instytucjom gospodarczym,

- przestępstwa przeciwko przedsiębiorstwom,

- przestępstwa przeciwko interesom finansowym państwa, 
- przestępstwa przeciwko środowisku popełniane w związku z prowadzoną aktywnością gospodarczą. ${ }^{13}$

Współczesna kryminologia wskazuje następujące cechy przestępczości gospodarczej:

- brak elementu przemocy, zastępowanej często pozorną legalnością,

- poważne straty materialne i niematerialne jako następstwo tego typu zachowań,

- wśród jej ofiar przeważają anonimowe osoby fizyczne oraz ważne gałęzie lub instytucje systemu gospodarczego,

- znaczna liczba sprawców rekrutowana jest z wyższych warstw społecznych. $^{14}$

W znacznej mierze cechy te odpowiadają cechom typowego białego kołnierzyka. Czyny popełniane w związku z tą przestępczością ciągle ewoluują. Można to zaobserwować w szeroko rozwijającej się bankowości elektronicznej, a także innych sferach działalności przestępczej.

\section{Wybrane przestępstwa na tle przestępczości białych kołnierzyków popełniane w Polsce}

\section{Nadużycie zaufania}

Przestępstwo z art. 296 kodeksu karnego jest refleksem nadużycia zaufania, jakie żywi właściciel firm do stopnia profesjonalizmu i uczciwości kierującego przedsiębiorstwem. ${ }^{15}$

Dobrem chronionym są tu zarówno interesy prawne podmiotów, które powierzyły zajmowanie się ich sprawami majątkowymi lub działalnością gospodarczą innej osobie, jak również interesy majątkowe Skarbu Państwa ${ }^{16}$.

Czynność wykonawcza polega na wyrządzeniu szkody. Omawiany czyn można popełnić zarówno przez działanie, jak i przez zaniechanie, podjęte wbrew obowiązkowi. Wyrządzenie szkody musi nastąpić przez nadużycie uprawnień lub niedopełnienie obowiązków. ${ }^{17}$

Przedmiotowym warunkiem odpowiedzialności za omawiane przestępstwo w jego typie podstawowym jest znaczna wartość wyrządzonej szkody majątkowej

J. Błachut, A. Gaberle, K. Krajewski, op. cit. s. 294.

Tamże, s. 295.

D. Czajka, Przestępstwa menedżerskie, Warszawa 2000, s. 108.

O. Górniok, Przestępstwa gospodarcze. Rozdział XXXVI i XXXVII kk Komentarz, Warszawa 2003, s. 16.

O. Górniok, (w:) Górniok i in., Kodeks karny. Komentarz. t. II, Gdańsk 2005, s. 426. 
(tj. przekraczająca dwustukrotność najniższego miesięcznego wynagrodzenia - art. 115 § 5 i kodeksu karnego).

Nadużycie zaufania jest przestępstwem indywidualnym. Jego podmiotem może być jedynie osoba szczególnie zobowiązana do zajmowania się sprawami majątkowymi lub działalnością gospodarczą osoby fizycznej, prawnej albo jednostki organizacyjnej niemającej osobowości prawnej (np. wydzielonej organizacyjnie jednostki przedsiębiorstwa lub instytucji posiadającej taką osobowość, spółki jawnej). ${ }^{18}$

Określony w art. $296 \S 1$ podstawowy typ przestępstwa ma w całości charakter umyślny. Tak więc zamiarem bezpośrednim lub co najmniej ewentualnym objęte musi być nie tylko nadużycie uprawnień lub niedopełnienie ciążących na sprawcy obowiązków, lecz także spowodowanie skutku w postaci znacznej szkody majątkowej (wyr. SN z 27 VI 2001 r., V KKN 49/99, Orz. Prok. i Pr. 2001, nr 12).

\section{Przekupstwo i sprzedajność menedżerów}

Kolejnym przestępstwem, które w sposób istotny charakteryzuje białe kołnierzyki, jest przekupstwo i sprzedajność menedżerów z art. 296a kodeksu karnego. Jest to przestępstwo stosunkowo nowe, ponieważ wprowadzone zostało do Kodeksu karnego nowelą z dnia 13 czerwca 2003 r. ${ }^{19}$

Przedmiotem ochrony czynów zabronionych przez komentowany przepis jest prawidłowe funkcjonowanie podmiotów prowadzących działalność gospodarczą. Nie ma znaczenia forma jednostki organizacyjnej prowadzącej działalność gospodarczą. Istotne jest tylko, by prowadziła ona taką działalność i była zorganizowana. ${ }^{20}$

Czynność sprawcza czynu określonego w § 1 polega na przyjęciu korzyści majątkowej lub osobistej.

Przestępstwo z art. 296a $§ 1 \mathrm{kk}$. jest przestępstwem indywidualnym. Podmiot czynu określony został funkcjonalnie i musi spełniać następujące kryteria:

- pełnić funkcję kierowniczą w jednostce organizacyjnej wykonującej działalność gospodarczą,

- posiadać z racji zajmowanego stanowiska lub pełnionej funkcji istotny wpływ na podejmowanie decyzji związanych z działalnością takiej jednostki. $^{21}$

Omawiany czyn można popełnić tylko umyślnie, w zamiarze bezpośrednim lub ewentualnym.

L. Gardocki, Prawo karne, Warszawa 2006, s. 318.

J. Skorupka, Prawo karne gospodarcze. Zarys wykładu, Warszawa 2007, s. 87.

O. Górniok, (w:) Górniok i in., Kodeks karny. Komentarz. t. II, Gdańsk 2005, s. 435.

J. Skorupka, op. cit. s. 89-90. 


\section{Pranie pieniędzy}

Pranie pieniędzy jest to proceder polegający na ukrywaniu istnienia nielegalnych dochodów, nadając im pozory legalności.

Przepisy dające podstawę karaniu za pranie pieniędzy chronią obrót gospodarczy przed wykorzystywaniem go i wzmacniają jednocześnie ochronę dóbr, takich jak: bezpieczeństwo powszechne, życie, zdrowie, wolność, budżety państw lub organizacji wspólnotowych.

Przedmiotem wykonawczym przestępstwa określonego w art. 299 § 1 są środki płatnicze, papiery wartościowe i wartości dewizowe, a także prawa majątkowe oraz mienie pochodzące z korzyści związanych z popełnieniem czynu zabronionego. Nie jest przy tym istotne, czy przedmioty te lub wartości majątkowe pochodzą bezpośrednio czy pośrednio z czynu zabronionego, tj. zostały uzyskane w wyniku obrotu korzyściami bezpośrednimi.

Zabronione zachowanie może polegać na przyjmowaniu, przekazywaniu lub wywozie za granicę, pomocy w przenoszeniu własności lub posiadania, a także na podejmowaniu innych czynności, które mogą udaremnić lub znacznie utrudnić stwierdzenie ich przestępnego pochodzenia lub miejsca umieszczenia.

Nie ma znaczenia, czy czyn sprawcy rzeczywiście skutkował ukryciem przestępnego pochodzenia przedmiotów lub utrudnił zabezpieczenie lub zajęcie. Wystarczy, jeżeli zamiarem sprawcy było spowodowanie takiego skutku. Dlatego omawiany czyn jest przestępstwem formalnym. ${ }^{22}$

\section{Uwagi na temat niektórych aspektów ściganie przestępczości białych kołnierzyków w Polsce}

Unormowania w polskim ustawodawstwie dotyczące ścigania przestępczości białych kołnierzyków są rozsiane po różnych ustawach. Faktem jest, że zapobieganie tej przestępczości jest utrudnione ze względu na aktualną sytuację korupcyjną w kraju, a także niską skuteczność odpowiednich instytucji kontroli.

Podstawowym organem posiadającym uprawnienia do ścigania tych przestępstw w Polsce jest Policja. W ramach jej struktur zostały powołane wydziały ds. przestępczości gospodarczej oraz Centralne Biuro Śledcze.

Z zadań Centralnego Biura Śledczego można wyszczególnić te mające istotne znaczenie dla przeciwdziałania przestępczości białych kołnierzyków. Są to: 
- przeciwdziałanie dokonywaniu przez grupy zorganizowane przestępstw polegających na oszustwach celno-podatkowych, związanych z obrotem towarami objętymi akcyzą i wyłudzeniami podatku VAT oraz podatku dochodowego,

- zwalczanie zorganizowanych grup przestępczych czerpiących zyski z nielegalnego obrotu paliwami,

- przeciwdziałanie niezgodnym z prawem działaniom związanym z niewłaściwym wykorzystywaniem i dystrybucją środków finansowych pochodzących bezpośrednio z Unii Europejskiej,

- rozpoznawanie i przeciwdziałanie zjawisku prania pieniędzy,

- zwalczanie oszustw w sferze obrotu finansowego na szkodę instytucji finansowych, banków, towarzystw ubezpieczeniowych, giełd, firm leasingowych, funduszy inwestycyjnych i gospodarczych na szkodę przedsiębiorców,

- zwalczanie korupcji m.in. w obszarze administracji państwowej, samorządowej i celnej, wymiaru sprawiedliwości i instytucji kontrolnych. ${ }^{23}$

Istotne zadania posiadają także wydziały ds. walki z przestępczością gospodarczą, do których należy zwalczanie przestępczości w zakresie:

- przestępstw komputerowych (szereg art. z rozdz. XXXIII, XXXIV, XXXV kk.),

- przestępstw z użyciem elektronicznych instrumentów płatniczych (art. 310, 287 kk.),

- fałszerstw i oszustw w związku z działalnością gospodarczą (rozdz. XXXVI kk.),

- przestępstw ubezpieczeniowych (art. 298, 286 kk.),

- przestępstw na szkodę interesów finansowych Unii Europejskiej (art. 297 kk.)

- prania pieniędzy (art. 299 kk.). ${ }^{24}$

Przestępczość białych kołnierzyków jest w obrębie zainteresowania agencji państwowych, a przede wszystkim Centralnego Biura Antykorupcyjnego, które w swoich zadaniach obejmuje kontrolę, której celem jest:

- ujawnianie i przeciwdziałanie przypadkom nieprzestrzegania przepisów ustawy o ograniczeniu prowadzenia działalności gospodarczej przez osoby pełniące funkcje publiczne;

- ujawnianie przypadków nieprzestrzegania określonych przepisami prawa procedur podejmowania i realizacji decyzji w przedmiocie: prywatyzacji i komercjalizacji, wsparcia finansowego, udzielania zamówień publicznych, rozporządzania mieniem jednostek lub przedsiębiorców oraz przyznawania 
koncesji, zezwoleń, zwolnień podmiotowych i przedmiotowych, ulg, preferencji, kontyngentów, plafonów, poręczeń i gwarancji kredytowych. ${ }^{25}$

Najistotniejsze zadanie do wykonania w dziedzinie ścigania ma jednak Prokuratura, ponieważ to od jej skuteczności zależy, czy będziemy mogli bronić naszą gospodarkę przed wyspecjalizowaną grupą przestępców, jaką niewątpliwie są tzw. „białe kołnierzyki”.

\section{Badania nad przestępczością gospodarczą na świecie}

Aktualnie na świecie badaniami nad szeroko rozumianą przestępczością gospodarczą zajmują się określone firmy. Największą, która bada rynek światowy w poszukiwaniu nadużyć, jest Price Water House Coopers ${ }^{26}$. Wydaje ona co dwa lata raporty dotyczące przestępczości gospodarczej na świecie.

Na podstawie tych raportów wykazano, że większa kontrola właścicieli firm i wprowadzanie odpowiednich instrumentów wpływa pozytywnie na wykrywanie oraz zmniejszanie przestępczości gospodarczej. Innym czynnikiem zmniejszającym podatność wyspecjalizowanych pracowników do popełniania czynów przestępnych jest tworzenie odpowiednich kodeksów etycznych, odpowiedni klimat pracy dający satysfakcję i możliwość samorealizacji. ${ }^{27}$

Straty z tytułu przestępczości gospodarczej:

- 2,2 mln \$ - lata 2003-2005

- 2,8 mln \$ - lata 2005-2007

Co ciekawe, okazuje się, że na świecie blisko $70 \%$ osób odpowiedzialnych za przestępstwa gospodarcze to mężczyźni, lecz coraz więcej kobiet popełnia przestępstwa gospodarcze, gdyż odsetek mężczyzn w latach 2003-2005 wynosił 78\%.

Typowy przestępca (w przypadku obu płci) ma od 31 do 50 lat (69\% badanych) i wyższe wykształcenie ( $52 \%$ badanych) ${ }^{28}$ odarczej,33,0,41249.html, stan prawny na dzień 18 marca 2009 r. 


\section{Organizacje międzynarodowe przeciwdziałające tzw. białym kołnierzykom}

Na świecie istnieją różnego rodzaju organizacje rządowe i pozarządowe, które wprowadzają odpowiednie programy mające na celu przeciwdziałanie przestępczości białych kołnierzyków.

Organizacją prowadzącą badania i posiadającą uprawnienia do ścigania jest National White Collar Crime Center. Opiera ona swoje działania o system „Internet Crime Complain Center” przy współpracy z Federalnym Biurem Śledczym.

Jest ona liderem na skalę światową w wykrywaniu, przeciwdziałaniu, dochodzeniu przestępstw gospodarczych oraz przestępstw internetowych (cyberprzestępczość). Wspomaga agencje rządowe w szkoleniu i w badaniach nad tymi przestępstwami.

Powstała w 1992 r. i posiada szeroko rozwiniętą strukturę, w skład której wchodzą agencje we wszystkich stanach Ameryki Północnej oraz 12 krajach świata, takich jak: Belgia, Kanada, Finlandia, Niemcy, Hongkong, Indie, Nowa Zelandia, Palau, Filipiny, Turcja, Ukraina i Wielka Brytania.

Od 2005 r. wydaje ona raporty ze swojej działalności. Najaktualniejszy pochodzi z działalności organizacji w latach 2007-2008.

W 2008 r. poprzez internetowy system „Internet Crime Complain Center” zgłoszone zostały 223,495 przypadki naruszeń. Sprawy wykryte w ten sposób przekazywane są organizacjom rządowym i lokalnym, które mają dostęp do systemu i mogą bezzwłocznie reagować na określone zdarzenie.

System wskazuje na rosnące straty państwa $\mathrm{z}$ tytułu przestępstw białych kołnierzyków. W opinii WCCC aktywność tej wyrafinowanej grupy przestępczej nigdy nie będzie łatwa w przeciwdziałaniu. ${ }^{29}$

\section{Sposoby przeciwdziałania}

Przestępczość białych kołnierzyków generuje olbrzymie zyski. Przestępcy starają się je zalegalizować, bądź ukryć pod tysiącem innych dokumentów. Organy państwowe powinny wykształcić odpowiednią instytucję, która umiałaby w sposób rzetelny i niezależny ocenić działania określonych firm, które przez zastosowanie odpowiednich systemów byłyby wykrywane przez organy ścigania.

$\mathrm{Na}$ świecie już działają podobne systemy mające na celu przeciwdziałanie zorganizowanej korupcji, przestępczości gospodarczej, umożliwiające łatwiejszy kon- 
takt obywatela z władzą. Zaimplementowanie ich do polskiego systemu prawnego powinno być celem pierwszorzędnym.

Przykładem takiej instytucji na świecie może być system Open. Został on wprowadzony przez władze miasta Seul w Korei Południowej. Jest to portal internetowy, w którym obywatele mogą załatwiać swoje sprawy obywatelskie bez konieczności wychodzenia z domu. Jego wykorzystanie umożliwia monitorowanie przez użytkownika całej procedury administracyjnej. System powstał w celu zwiększenia przejrzystości w procedurach administracyjnych, ułatwienia obywatelom procesu składania wniosków i aplikacji oraz poprawieniu wiarygodności administracji publicznej przez zaoferowania dostępu do informacji na zasadzie uczciwości i obiektywnych kryteriów oceniania. Umożliwia on przeciwdziałanie zorganizowanej korupcji, ukierunkowanej na odseparowanie obywatela od urzędnika państwowego. ${ }^{30}$

Amerykański system internetowy „Internet Crime Complain Center” jest kolejnym przykładem reakcji ze strony władz na to, w jaki sposób przestępczość ewoluuje w czasach globalizacji, a wykorzystanie Internetu jako środka komunikacji pomiędzy obywatelem a władzą okazało się sposobem tanim i funkcjonalnym. Służy on nie tylko zwalczaniu przestępczości białych kołnierzyków, ale także wspomaga tworzenie odpowiednich programów prewencyjnych.

W Polsce władze ograniczają się do przedstawiania swoich instytucji w Internecie, co de facto również przyczynia się do większej świadomości prawnej otaczającej nas rzeczywistości.

W walce z ówczesną przestępczością gospodarczą najistotniejszym jest wybór właściwych sposobów komunikacji, bo to od jej szybkości zależy, czy władze zdążą zareagować w odpowiednim czasie na dane zjawisko przestępcze.

Problemem we wdrażaniu w Polsce takiego systemu są niewątpliwie bariery mentalne. Jak potwierdzają badania społeczne, przeciętnego Polaka cechuje duży stopień tolerancji i pobłażliwości dla licznych zjawisk patologicznych, do których niewątpliwie należy „mało widoczna” przestępczość białych kołnierzyków.

Przestępcy w białych kołnierzykach w okresie kryzysu gospodarczego, a jednocześnie olbrzymich dotacji z Unii Europejskiej, będą wykorzystywać swoje uprzywilejowane pozycje do popełniania różnego rodzaju oszustw i wyprowadzania kapitału z przedsiębiorstw na ogromną skalę. Stąd wiedza na temat amerykańskich doświadczeń dotyczących przeciwdziałania przestępczości tzw. białych kołnierzyków może być niezwykle przydatna w europejskich realiach. 


\section{SUMMARY}

White collar criminality in the modern world is a problem that American criminologist have been studying since the 1940s. It is very important in our Polish community to solve the problem of white collar crimes. We can't stand and watch white collar individuals committing crimes without responsibility for their behavior. This article demonstrates how those criminals work and what corporate crimes they can commit. It shows how to prevent corporate crimes and where we can find them in our community. In the USA, white collar criminals are well-known in the justice system. Polish authors didn't focus on those criminals, but characteristic of Polish corporate criminals are similar to those of white collar criminals. There are many theories about white collar crimes, so the author chooses only those which agree with his opinion and are the most critical to understanding those people's behavior. This article is a brief description that criminality nowadays is growing quickly. In terms of European Union donation these criminals will play a part in fraud in a very expensive area. 